\title{
Existing Noise Level at Railway Stations in Malaysia
}

\author{
Shahiron Shahidan,"*, Mohamad Zulkhairi Md Maarof ${ }^{2}$, Nurul Izzati Raihan Ramzi \\ Hannan $^{3}$, and Noorwirdawati $\mathrm{Ali}^{4}$ \\ 1, 3, ${ }^{4}$ Jamilus Research Centre, Faculty of Civil and Environmental Engineering, Universiti Tun \\ Hussein Onn Malaysia. \\ ${ }^{2}$ Faculty of Engineering Technology, Universiti Tun Hussein Onn Malaysia, 86400 Batu Pahat, Johor, \\ Malaysia.
}

\begin{abstract}
Railway transportation known as one of the most environmental friendly transportation mode. However, the significance problems of railway transportation are noise pollution and negatively impact the wellbeing of the whole community. Unfortunately, there has been lack of public awareness about the noise level produce by the railway transportation in Malaysia. This study investigates the noise level produced by railway transportation in Malaysia specifically by Keretapi Tanah Melayu Berhad (KTMB). Methods of collecting existing noise level at railway stations in Malaysia are briefly discussed in this study. The finding indicates that the noise level produced by the railway transportation in Malaysia which is by KTMB is considered as dangerous to human being and also exceed the noise limit that has been assigned by Department of Environment Ministry of Natural Resources and Environment of Malaysia. A better noise barrier and improved material should be developed to mitigate the existing noise level produced by railway transportations in Malaysia.
\end{abstract}

\section{Introduction}

Unnecessary noise is the most cruel abuse of care which can be inflicted on either the sick or the well [1]. Plus, the noise pollution also reported as a primary cause of sleep deprivation [1]. Recent investigations indicate that railway noise leads to significant sleep fragmentation and cardiovascular activations during sleep and to subjective distress as well as long-term effects of prolonged exposure to noise [2,3][24]. The World Health Organization (WHO) estimates that more than 1 million healthy life years are lost every year in western Europe due to noise exposure [4]. Railway noise causes much nuisance to the residents near the railway tracks [5][27]. With the growth of cities, societies is increasingly questioning these problems and people living in the proximities of railway tracks consider noise the most serious environmental problem [6]. Research on cardiovascular disease has specifically explored the hypothesis that exposure to transportation noise increases the risk for ischemic heart disease (IHD) [7]. Night-time

* Corresponding author: shahiron@uthm.edu.my 
freight train noise and vibration also can accelerate heart rate during sleep which may in turn be linked to cardiovascular disease (CVD) []. The difference in dose-response relationships for railway and road traffic noises between western and eastern countries was ascribed to the distance between railways and houses, the position of the balcony and the attitudes of the residents toward the source of the noise [9-11].

The events corresponding to noise sources, different from the transit noise but associated anyway with the rail such as manoeuvring, loading and unloading, truck movements, braking, squeals, whistles, arrivals and departures of trains, speakers, passengers, internal works, generators, bells and crossings were labelled as "unconventional noise sources" whilst the rail transit and the passage of freight trains were separately identified [11]. To reduce this noise, different measures could be implemented in different places such as at the source, between the source and the receiver and at the receiver [12][26]. Rail transport which is ecologically and economically and significantly accepted, faces the demand to guarantee on such values of noise emission that do not exceed the permitted noise limits monitored in tracks for different speed zones which standard, speed and high speed track [13]. Noise load of the rail transport can be reduced by different building and technical noise arrangements which can generally can be divided into active and passive [13]. Active noise arrangements are such modifications of noise sources which involve certain modifications on the railway vehicles and railway tracks while the passive noise arrangements are such measures that absorbing the noise already emitted to the surrounding such as noise barrier, noise tunnels and noise windows [13].

However, in order to mitigate the effect of noise pollution cause by railway transportation, the existing noise level produced by KTMB train services should be measured. A good knowledge of the nature and relative strengths of the various sources of noise is a fundamental requirement if railway noise is to be understood and moreover to be reduced [14]. The basic reason for investigating source mechanism is that, in many cases, due to system considerations, simple shielding of the sources is not possible [14][25].

The Malaysian Department of Environment had published a guidance on acceptable noise limits for various types of land use and human actitivities. This is to provide a guideline for the acceptance criteria for quantitative assessment of noise to define disturbance or otherwise for any new developments or projects. Table 1 represents the limiting sound level guideline for railway transportations.

Table 1. Limiting sound level for railway including transits for new development and re-alignments

\begin{tabular}{|l|l|l|l|}
\hline $\begin{array}{l}\text { Receiving Land Use } \\
\text { Category }\end{array}$ & $\begin{array}{l}\text { Day time } \\
7.00 \mathrm{am}-10 \mathrm{pm}\end{array}$ & $\begin{array}{l}\text { Night time } \\
10.00 \mathrm{pm}-7.00 \mathrm{am}\end{array}$ & $\begin{array}{l}\text { Lmax } \\
\text { (Day \& Night) }\end{array}$ \\
\hline $\begin{array}{l}\text { Noise Sensitive Areas } \\
\text { Low Density } \\
\text { Residential Areas }\end{array}$ & $60 \mathrm{dBA}$ & $50 \mathrm{dBA}$ & $75 \mathrm{dBA}$ \\
\hline $\begin{array}{l}\text { Suburban And Urban } \\
\text { Residential Areas }\end{array}$ & $65 \mathrm{dBA}$ & $60 \mathrm{dBA}$ & $80 \mathrm{dBA}$ \\
\hline Commercial, Business & $70 \mathrm{dBA}$ & $65 \mathrm{dBA}$ & $80 \mathrm{dBA}$ \\
\hline Industrial & $75 \mathrm{dBA}$ & $65 \mathrm{dBA}$ & NA \\
\hline
\end{tabular}

Furthermore, for reasons of efficiency in terms of reduction, the depth of knowledge necessary for each source has to be considered, with respect to the state of the art in the subject [14][15]. One of the solutions to reduce noise is by using noise barrier. However, the function of the noise barrier is only as noise reducer but not completely block the sound annoyance [15][16]. The noise level produced by the KTMB train services must be measured to be characterized and analysed either it is in acceptance level or considered dangerous to living things. 
The aim of this paper is to investigate the existing noise level produced by all KTMB railway services such as intercity train services, komuter services, Electric Train Services (ETS) and freight train.

\section{Data collections method}

\subsection{Sound Level Meter (SLM)}

The data collections being conducted using Sound Level Meter (SLM) type of ISO-TECH SLM-1352N. The SLM was located at two different locations which are as near as possible to the operating trains within permissible area along the train platform to measure the maximum noise level produced by the operating trains and also located away from the operating train where the possible barriers are exist such as trees, building and wall. Fig. 1 displays the closest distance of SLM located to the noise source of ETS at Gemas Railway Station while Fig. 2 shows the location of SLM to the closest of diesel engine noise source available on locomotive diesel train and Figure 3 represent the SLM being located as close as possible to the pantograph noise available on ETS.

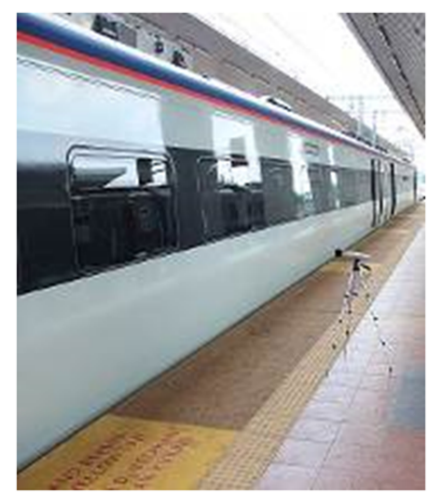

Fig.1 : Location of SLM near Electric Train Service (ETS)

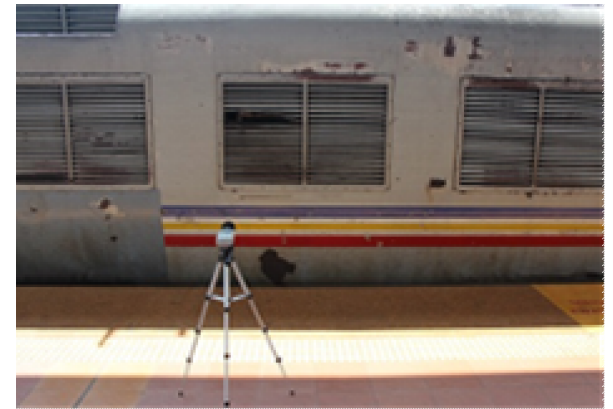

Fig.2 : Location of SLM near engine of KTM Intercity Diesel Train

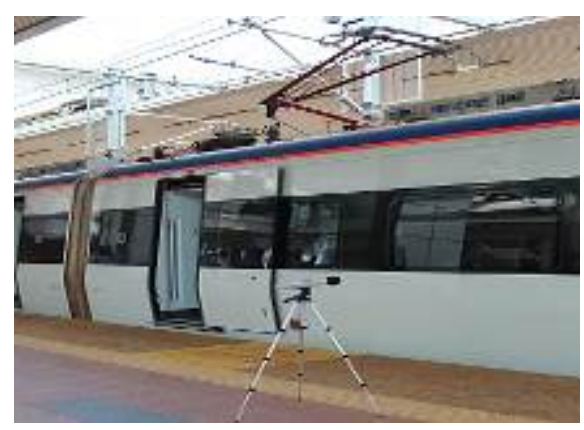

Fig.3 : Location of SLM near pantograph of the ETS

The measurement process was conducted during the day and night to be compared with the noise regulation that had been published by the Department of Environment Ministry of Natural Resources and Environment Malaysia [17]. This is to determine either the existing noise level produce by KTMB train services is considered safe for human or not. 


\subsection{Selection of study location}

There are four preferred study locations which are Kluang Railway Station, Segamat Railway Station, Gemas Railway Station and Kuala Lumpur Railway station. The selected study locations were based on the different criteria which involves new train and old train line. The old system single track still being used from Gemas to the south of west Malaysia which end at Johor Bahru Sentral before entering Singapore. The construction of a new double track system from Gemas to Johor Bahru Sentral is still in plan and does not started yet. It involves only old train systems which are locomotive intercity diesel train and freight train. However, a new and modern Electric Train Services (ETS) available from Gemas towards the north of west Malaysia. Thus, this noise level measurement involves both old and new train system provided by KTMB train services. Figure 4 show KTMB intercity train services with yellow crossed mark shows the locations of noise level measurements being conducted which are Kuala Lumpur Railway Station, Gemas Railway Station, Segamat Railway Station and Kluang Railway Station.

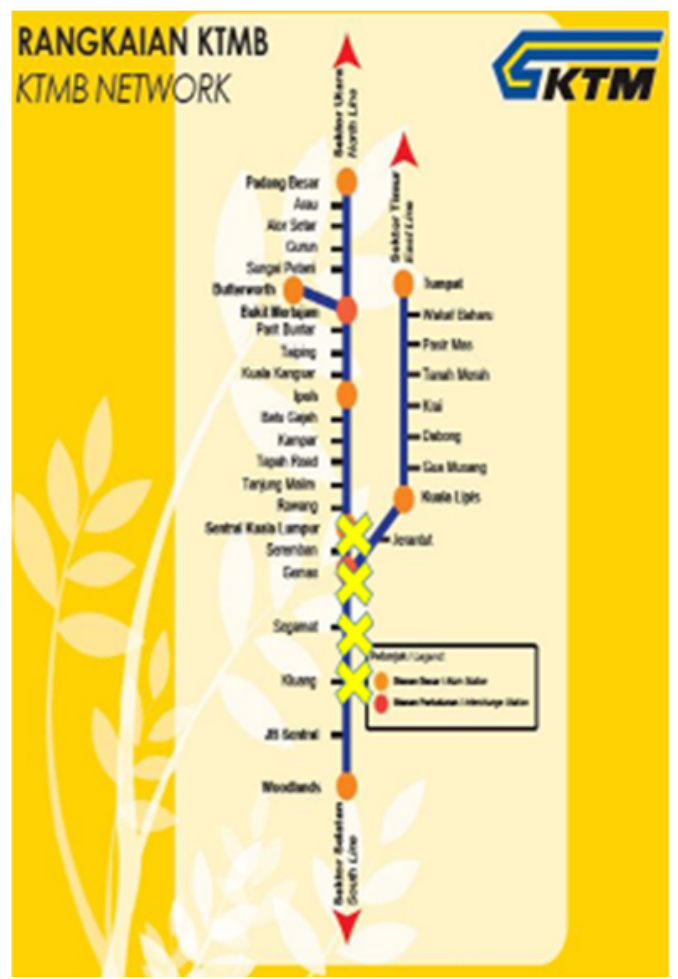

Fig.4 : Roadmap of KTMB intercity train services

\section{Result and discussion}

\subsection{Different locations}

The noise levels recorded are varies from each stations. There are several factors influence the noise level produced at the railway stations such as the design of the station and surrounding area of each particular stations. Table 1 reveals the maximum and minimum noise level recorded at each railway stations involve in this study.

Table 2. Noise level recorded at different railway stations

\begin{tabular}{|l|c|c|c|c|}
\hline $\begin{array}{l}\text { Noise } \\
\text { level }\end{array}$ & $\begin{array}{c}\text { Kluang } \\
(\mathrm{dB})\end{array}$ & $\begin{array}{c}\text { Segamat } \\
(\mathrm{dB})\end{array}$ & $\begin{array}{c}\text { Gemas } \\
(\mathrm{dB})\end{array}$ & $\begin{array}{c}\text { Kuala Lumpur } \\
(\mathrm{dB})\end{array}$ \\
\hline Minimum & 53.1 & 46.4 & 43.2 & 57.9 \\
\hline Maximum & 89.6 & 85.4 & 93.9 & 90.4 \\
\hline
\end{tabular}

All these stations are open structure without enclosure except for the Kuala Lumpur Railway station which has fully enclosure along the stations and platform. Table 1 shows that the highest noise level recorded is at Gemas Railway Station. This is because the 
Sound Level Meter (SLM) is able to be located as close as possible to the train noise sources such as the diesel engine or the rail track.

Kuala Lumpur Railway station recorded the highest ambient noise without the presence of the trains. This is possibly due to reverberation phenomenon where it is a result of multiple reflection of sound wave. A sound wave in an enclosed or semi-enclosed environment will be broken up as it is bounced back and forth among the reflecting surfaces as in this case the noise produced by the human activities, station announcement through the loudspeaker upon train arrival and departure and also noise from building air conditioning system available at the station. As a result, it contributed to the significant increase of the ambient noise compared to the other ambient noise measured at other railway stations which typically range between 45 to $55 \mathrm{dBA}$ without the presence of the train. Table 1 reveals that Kluang Railway Station recorded a high minimum noise levels compared to other railway station despite of having an open sructure of railway station. This is because the present of local food restaurant at the railway station produce a higher noise level from human activities. Fig. 6 indicates the Kuala Lumpur Railway Station with enclosed roof top structure.

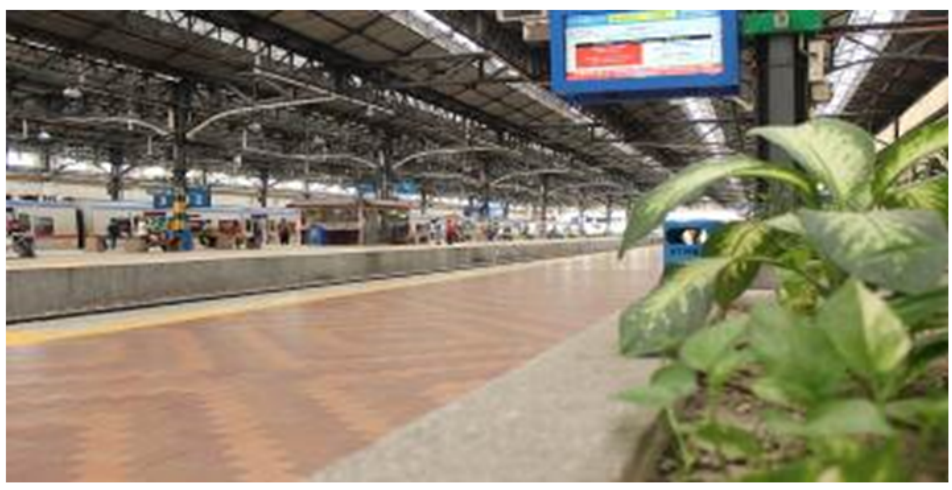

Fig. 5. Kuala Lumpur Railway Station with enclosed roof top structure

\subsection{Different types of trains}

Different types of trains produce different levels of noises. The highest level of noise for KTM train services is recorded from the intercity diesel train and freight train. The other two types of KTM train services which are KTM Komuter and ETS produces a lower noise level compared to the old diesel train. Table 2 represents the comparison of noise level and percentage difference compared to permissible noise level according to the guideline of Department of Environment provided by Ministry of Natural Resources and Environment Malaysia . The oldest train used by the KTMB is the diesel locomotives operate for KTM intercity passenger services and KTM Kargo services. Currently, the diesel locomotives used by KTM are 19 class, 23 class, 24 class, 25 class, 26 class, 29 class and YDM4 which Y stood for metre gauge, D for diesel and $\mathrm{M}$ for mixed loads.

All KTM locomotive types of train use diesel and produce a high noise level during operation either during carrying passengers or loads for freight train. KTM Komuter is first introduced in 1995 as Malaysia's first electric train services. It provides all-stop local commuter rail services across KTM's electrified double track sectors primarily linking the suburbs to and from the city centre. The electric powered KTM Komuter produce low noise level compared to the old one KTM diesel locomotives. It divided into two operating sector which are northern sector and Klang Valley sector. 
Table 3. Percentage difference of different types of trains

\begin{tabular}{|l|l|l|l|l|}
\hline Type of trains & $\begin{array}{l}\text { Freight } \\
\text { train }\end{array}$ & $\begin{array}{l}\text { Locomotive } \\
\text { Diesel Train }\end{array}$ & $\begin{array}{l}\text { KTM } \\
\text { Komuter }\end{array}$ & $\begin{array}{l}\text { Electric Train } \\
\text { Services (ETS) }\end{array}$ \\
\hline $\begin{array}{l}\text { Noise levels } \\
\text { measured }\end{array}$ & 93.9 & 93.9 & 79.9 & 72.2 \\
\hline $\begin{array}{l}\text { Permissible } \\
\text { noise level }\end{array}$ & 65 & 65 & 70 & 70 \\
\hline $\begin{array}{l}\text { Percentage of } \\
\text { difference \% }\end{array}$ & $44.46 \%$ & $44.46 \%$ & $14.14 \%$ & $3.14 \%$ \\
\hline
\end{tabular}

Table 2 revealed that the intercity diesel locomotive for passenger and freight train are the only KTM train services which recorded the highest and maximum noise level that SLM able to record which is $93.9 \mathrm{dBA}$. The latest KTM train services is Electric Train Services (ETS) which produced the lowest noise level measured. It run at a maximum speed of $160 \mathrm{~km} / \mathrm{h}$ and the operational speed is up to $140 \mathrm{~km} / \mathrm{h}$ on electrified double track sectors between Gemas and Padang Besar. Table 2 also indicated ETS recorded the lowest maximum noise level compared to other trains services provided by the KTM.

\subsection{Different distances of noise receiver}

The sound level meter (SLM) recorded a different values of noise levels at different distances. Table 3 display the comparison of noise levels produced by the KTM train services at different distances of noise receiver. It shows that the highest noise level recorded is the closest to the noise source which is within $1 \mathrm{~m}$. The second highest noise level recorded is $5 \mathrm{~m}$ from the noise level and the third highest and the lowest noise level recorded is within $10 \mathrm{~m}$ and $15 \mathrm{~m}$ from the noise source respectively.

Table 4. Noise levels produced at various distances

\begin{tabular}{|l|c|c|c|c|}
\hline Distance & $\mathbf{1 ~ \mathbf { ~ m }}$ & $\mathbf{5 ~ \mathbf { ~ }}$ & $\mathbf{1 0 ~} \mathbf{~ m}$ & $\mathbf{1 5 ~ \mathbf { ~ m }}$ \\
\hline Noise level (dBA) & 93.9 & 93.9 & 77.8 & 57.9 \\
\hline $\begin{array}{l}\text { Permissible } \\
\text { noise level (dBA) }\end{array}$ & 60 & 60 & 60 & 60 \\
\hline Percentage of difference \% & 56.5 & 56.5 & 29.6 & -3.626 \\
\hline
\end{tabular}

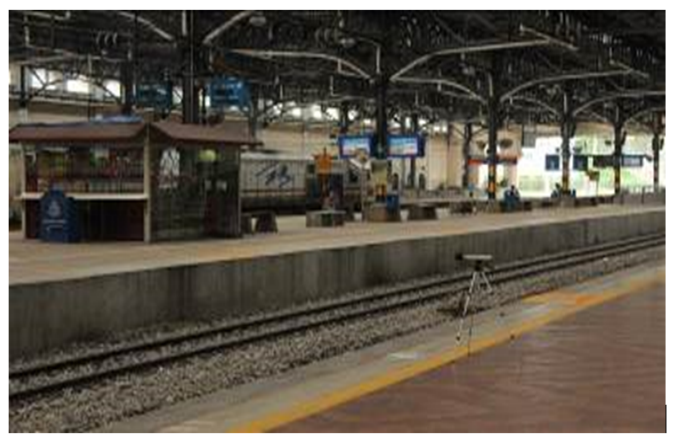

Fig. 6. SLM located at different platform $15 \mathrm{~m}$ away from train passing-by

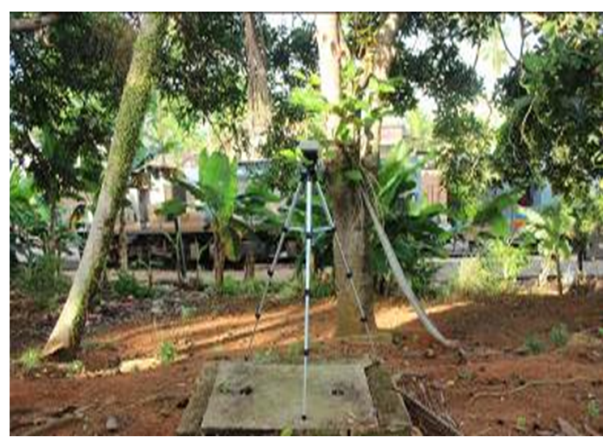

Fig. 7. SLM located away from train noise with the presence of physical barriers

It shows that the higher the distances between the noise source and the receiver, the lower the noise level received by the receiver. The noise level measured decrease when the SLM device is located far away from the railway track or the noise source. Fig. 6 shows the 
location of the SLM which is located within $15 \mathrm{~m}$ away from the noise source while Figure 9 represents the SLM located within $10 \mathrm{~m}$ away from the train noise with the presence of physical barriers such as trees and bushes. This shows that increase in distance between noise source and the receiver or if there is any presence of barrier between noise source and the receiver will significantly reduce the noise level received by the receiver $[18,19]$.

\subsection{Day vs night}

The Department of Environment Ministry of Natural Resources and Environment Malaysia had provided an Environmental Noise Limits and Controls as guidance for various types of land use and human activities. The guideline as shown in Table 5 reveals the noise acceptance criteria for quantitative assessment of noise to define disturbance or otherwise. Table 5 reveals that the Department of Environment had provided a strict noise level of acceptance criteria during the night since the nocturnal exposure to a traffic or transportation noise constitute a real probe for sleep and quality of life [20][23]. Thus, the percentage difference of exceeding noise level produced by KTM train services is higher during night time. The selection of receiving land use category is based on where the data collection had been conducted during day and night which are at Segamat and Kuala Lumpur. The reason behind the selected study locations is to compare the noise level produced at the low residential area which is at Segamat with the noise levels produced at the commercial or business area which is in Kuala Lumpur. Nocturnal noise disturbance mainly concern detrimental effects on cardiovascular reactivity and sleep architecture with the loss of the most critical sleep stages involved in physical and metal recovery [21][22].

Table 5. Limiting sound level for railway including transits for new development and re-alignments

\begin{tabular}{|l|c|c|}
\hline Receiving Land Use Category & $\begin{array}{c}\text { Day time } \\
7.00 \mathrm{am}-10 \mathrm{pm}\end{array}$ & $\begin{array}{c}\text { Night time } \\
10.00 \mathrm{pm}-7.00 \mathrm{am}\end{array}$ \\
\hline $\begin{array}{l}\text { Noise Sensitive Areas Low } \\
\text { Density Residential Areas }\end{array}$ & $60 \mathrm{dBA}$ & $50 \mathrm{dBA}$ \\
\hline Commercial, Business & $70 \mathrm{dBA}$ & $65 \mathrm{dBA}$ \\
\hline
\end{tabular}

Table 6. Noise level recorded during day and night

\begin{tabular}{|l|c|c|c|c|}
\hline Location & $\begin{array}{c}\text { Recorded Noise } \\
\text { Level During } \\
\text { Day Time } \\
(\mathrm{dBA})\end{array}$ & $\begin{array}{c}\text { Percentage } \\
\text { Difference } \\
\text { During Day Time } \\
(\%)\end{array}$ & $\begin{array}{c}\text { Recorded Noise } \\
\text { Level During } \\
\text { Night Time } \\
(\mathrm{dBA})\end{array}$ & $\begin{array}{c}\text { Percentage } \\
\text { Difference During } \\
\text { Night Time (\%) }\end{array}$ \\
\hline Segamat & 93.9 & 56.5 & 93.9 & 87.8 \\
\hline Kuala Lumpur & 83.8 & 19.71 & 89.6 & 37.85 \\
\hline
\end{tabular}

\section{Conclusions}

This study presents the result of existing noise level available at the different locations of KTMB railway stations which are Kuala Lumpur Railway Station, Gemas Railway Station, Segamat Railway Station and Kluang Railway Station. Based on the result of the study the following conclusion may be presented:

i) The old conventional diesel locomotive train produces higher noise level.

ii) Increase in distance between the noise source and the receiver will significantly reduce the noise level receive by the receiver. 
iii) The presence of the barrier between the noise source and the receiver will reduce the noise level received by the receiver.

iv) The ambient noise in enclosure structure is higher compared to the open air structure.

v) The noise produced by the new and fully electrified train which is ETS produce lower noise compared to other type of KTM train Services such as diesel powered locomotive train.

The authors would like to express their deepest appreciation to the Ministry of Higher Education Malaysia, Universiti Tun Hussein Onn Malaysia for funding the research under FRGS grant vot 1576.

\section{References}

[1] R. Khaiwal, T. Singh, J.P. Tripathy, S. Mor, S. Munjal, B. Patro, and N. Panda, Assessment of noise pollution in and around a sensitive zone in North India and its non-auditory impacts, Sci. Total Environ., 566-567, 981-987 (2016)

[2] S. Shahidan, N.M. Bunnori, N. Md Nor, and S.R. Basri, Damage severity evaluation on reinforced concrete beam by means of acoustic emission signal and intensity analysis, 2011 IEEE Symposium on Industrial Electronics and Applications, 337-341, (2011)

[3] G.J.L. Micheli, and S. Farné, Urban railway traffic noise: Looking for the minimum cost for the whole community, Appl. Acoust., 113, 121-131 (2016)

[4] M. Gouveia, M. Borges, J. Costa, and A.V. Carneiro, Burden of disease from hypercholesterolemia in Portugal, Rev. Port. Cardiol., 23, 255-270 (2004)

[5] N. Ozkurt, D. Sari, A. Akdag, M. Kutukoglu, and A. Gurarslan, Modeling of noise pollution and estimated human exposure around Istanbul Atatürk Airport in Turkey, Sci. Total Environ., 482-483, 486-492 (2014)

[6] F. Bunn, and P.H.T. Zannin, Assessment of railway noise in an urban setting, Appl. Acoust., 104, 16-23 (2016)

[7] D. Vienneau, C. Schindler, L. Perez, N. Probst-Hensch, and M. Röösli, The relationship between transportation noise exposure and ischemic heart disease: A meta-analysis, Environ. Res., 138, 372-380 (2015)

[8] M.G. Smith, I. Croy, M. Ögren, O. Hammar, and K.P. Waye, Freight trains, nocturnal vibration and noise, and their physiological effects during sleep, 11th Int. Congr. Noise as a Public Heal. Probl., 1-8 (2014)

[9] P. Lercher, B. de Greve, D. Botteldooren, and J. Rüdisser, A comparison of regional noise-annoyance-curves in alpine areas with the European standard curves, Proc. 9th Congr. Int. Comm. Biol. Eff. noise (ICBEN 2008), 562-570 (2008)

[10] T. Morihara, T. Sato, and T. Yano, Comparison of dose-response relationships between railway and road traffic noises: The moderating effect of distance, J. Sound Vib., 277, 559-565 (2004)

[11] G. Licitra, L. Fredianelli, D. Petri, and M. Angela, Science of the total environment annoyance evaluation due to overall railway noise and vibration in Pisa urban areas, Sci. Total Environ., (2015)

[12] A. Tumavičè, A. Laurinavičius, A. Jagniatinskis, and A. Vaitkus, Environmental noise mitigation measures for Lithuanian Railway Network, Transp. Res. Procedia, 14, 2704-2713 (2016)

[13] A. Pultznerov, and L. Izvolt, Structural modifications, elements and equipment for railway noise reduction, Procedia Eng., 91, 274-279 (2014)

[14] C. Talotte, P.E. Gautier, D.J. Thompson, and C. Hanson, Identification, modelling and reduction potential of railway noise sources: A critical survey, J. Sound Vib., 267, 447-468 (2003) 
[15] H. Halim, R. Abdullah, A. Abdullah, A. Ali, and M. J. Mohd, Effectiveness of existing noise barriers: Comparison between vegetation, concrete hollow block, and panel concrete, Procedia Environ. Sci., 30, 217-221 (2015)

[16] S. Shahidan, H.B. Koh, A.M.S. Alansi, and L.Y. Loon, Strength development and water permeability of engineered biomass aggregate pervious concrete, MATEC Web Conf., 47, 2-7 (2016)

[17] The Planning Guidelines for Environmental Noise Limits and Control, Vol. 1, Department of Environment Ministry of Natural and Environment, Malaysia, (2016)

[18] S. Shahidan, R. Pullin, K.M. Holford, M.B.N, and N. Nor, Quantitative evaluation of the relationship between tensile crack and shear movement in concrete beams, Adv. Mater. Res., 626, 355-359 (2013)

[19] M. Abdul Rahim, N. M. Ibrahim, Z. Idris, Z. M. Ghazaly, S. Shahidan, N. L. Rahim, L. A. Sofri, and N. F. Isa, "Properties of Concrete with Different Percentange of the Rice Husk Ash (RHA) as Partial Cement Replacement," Mater. Sci. Forum, vol. 803, pp. 288-293, (2014).

[20] P. Tassi, O. Rohmer, A. Bonnefond, F. Margiocchi, F. Poisson, and S. Schimchowitsch, Long term exposure to nocturnal railway noise produces chronic signs of cognitive deficits and diurnal sleepiness, J. Environ. Psychol., 33, 45-52 (2013)

[21] D. Halperin, Environmental noise and sleep disturbances: A threat to health?, Sleep Sci., 7, 209-212 (2014)

[22] J.M. Irwan, M.M.K. Annas, A.K. Aeslina, R.M. Asyraf, and S.K. Faisal, Cracking propagation of reinforced concrete using polyethylene terephtalate (PET) bottles as fine aggregate, Advanced Materials Research, 911, 474-478 (2014)

[23] M.H. Wan Ibrahim, N. Jamaludin, J.M. Irwan, P.J. Ramadhansyah, and A. Suraya Hani, Compressive and flexural strength of foamed concrete containing polyolefin fibers, Adv. Mater. Res., 911, 489-493 (2014)

[24] N.I.R. Ramzi hannan, S. Shahidan, M.Z. Maarof, and N. Ali, Physical and chemical properties of coal bottom ash (CBA) from Tanjung Bin Power Plant, IOP Conf. Ser. Mater. Sci. Eng., 160, 12056 (2016)

[25] S. Shahidan, S.S.M. Zuki, and N. Jamaluddin, Damage grading system for severity assessment on concrete structure, Case Stud. Constr. Mater., 5, 79-86 (2016)

[26] S. Shahidan, S.S. Mohd Zuki, M.A. Rahim, and N. Ali, Amplitude distribution of emission wave for cracking process, MATEC Web Conf., 47, 2-8 (2016)

[27] S. Shahidan, N.I.R.R. Hannan, M.Z. Maarof, and A.S. Leman, A comprehensive review on the effectiveness of existing noise barriers commonly used in the railway industry, MATEC Web Conf., 87, 1-8 (2017) 